\title{
Obesity, Hypertension, Social Determinants of Health, and the Epidemiologic Transition among Traditional Amazonian Populations
}

Running title: SDH and the Epidemiologic Transition in Amazonia

Hilton P. Silva ${ }^{1}$

1. Programa de Pós-Graduação em Antropologia \&

Programa de Pós-Graduação em Saúde, Ambiente e Sociedade na Amazônia

Laboratório de Estudos Bioantropológicos em Saúde e Meio Ambiente

Instituto de Filosofia e Ciências Humanas

Universidade Federal do Pará, Belém, PA, Brazil

Cristina Padez ${ }^{2}$

2. Department of Life Sciences

Research Centre for Anthropology and Health

University of Coimbra, Portugal

Edila A. F. Moura ${ }^{3}$

3. Programa de Pós-Graduação em Sociologia e Antropologia

Instituto de Filosofia e Ciências Humanas

Universidade Federal do Pará \&

Instituto de Desenvolvimento Sustentável Mamirauá

Belém, PA, Brazil

Lígia A. Filgueiras ${ }^{1,4}$

1. Programa de Pós-Graduação em Antropologia

Laboratório de Estudos Bioantropológicos em Saúde e Meio Ambiente

Instituto de Filosofia e Ciências Humanas

Universidade Federal do Pará, Belém, PA, Brazil

4. Universidade do Estado do Pará-

Departamento de Ciências Naturais

Centro de Ciências Sociais e de Educação

Belém, PA, Brazil 


\section{Address for Correspondence}

Hilton P. Silva

Universidade Federal do Pará

Cidade Universitária Prof. José Rodrigues da Silveira Netto

Instituto de Filosofia e Ciências Humanas

Laboratório de Antropologia Arthur Napoleão Figueiredo

66075-110, Belém, Pará, Brazil

E-mail: hdasilva@ufpa.br

Phone: (91) 98867-8728 


\section{Obesity, Hypertension, Social Determinants of Health, and the Epidemiologic Transition among Traditional Amazonian Populations.}

Abstract

Background: The health and nutritional situation of adults from three rural vulnerable Amazonian populations are investigated in relation to the Social Determinants of Health $(\mathrm{SDH})$ and the epidemiologic transition.

Aim: To investigate the role of the environment and the SDH on the occurrence of chronicdegenerative diseases in these groups.

Subjects and Methods: Anthropometric, blood pressure, and demographic data were collected in adults from the RDS Mamirauá, AM (n=149), Flona Caxiuanã, PA (n=146), and quilombolas, PA $(n=351)$, populations living in a variety of socio-ecological environments in the Brazilian Amazon.

Results: Adjusting for the effect of age, quilombola men are taller $(\mathrm{F}=9.85 ; p<0.001)$, and quilombola women present with higher adiposity $(\mathrm{F}=20.43 ; p<0.001)$ and are more overweight/obese. Men from Mamirauá present higher adiposity ( $\mathrm{F}=9.58 ; p<0.001)$. Mamirauá women are taller $(\mathrm{F}=5.55 ; p<0.01)$ and have higher values of waist circumference and subscapular/triceps index. Quilombolas present higher prevalence of hypertension in both sexes, and there are significant differences in rates of hypertension among the women $\left(X^{2}=17.45 ; p<0.01\right)$. The quilombolas are more dependent on government programs, people from Mamirauá have more economic resources, and the group from Caxiunã have the lowest SES.

Conclusion: In these populations, the SDH play a key role in the ontogeny of diseases, and the "diseases of modernity" occur simultaneously with the always present infectoparasitic pathologies, substantially increasing social vulnerability. 
Key-words: Riverine, Quilombolas, Health, Nutrition, Anthropology 


\section{Obesity, Hypertension, Social Determinants of Health, and the Epidemiologic Transition among Traditional Amazonian Populations}

The Amazon is one of the last ecological frontiers of the planet. In recent decades it has been the focus of intense social, economic and environmental changes which have led to important epidemiologic implications for the local populations (Piperata and Dufour, 2007; Piperata et al., 2011; Melo and Silva, 2015; Silva 2004a,b, 2011).

Studies about nutrition and health of non-indigenous traditional populations of the Brazilian Amazon such as caboclo/ribeirinhos and quilombolas are still limited. Only recently, due to new governmental policies, more attention has been given to social, economic, territorial and health aspects of these groups (Brasil, 2007a,b,c). However, because of logistic difficulties, and high costs involved with investigations of smaller and more geographically isolated populations, research reporting on their health and nutrition situation continues to be a challenge. In this article data related to the evaluation of adult health, nutritional status and blood pressure, for three different rural groups representing an important part of Amazonian social diversity, are presented. These groups are considered vulnerable due to their ethnic and socio-ecological conditions (Adams, 2002; Adams, et al. 2006; Brasil, 2007a; Freitas et al., 2011; Gomes et al., 2013; Lima and Pereira, 2007; Silva, 2006), and here their situation is analysed from a Social Determinants of Health (SDH) perspective (CSDH, 2005; CNDSS, 2008; Marmot, 2001; Rose, 1985).

According to Rose (1985) it is necessary to look at the "causes of causes" of disease, that is, to go beyond the disease of the individual to the reasons why people become sick. When this is done it becomes clear that the primary determinants of diseases, in any population, are social and economic rather than simply biologic. Even though genetic factors may have a strong influence on individual susceptibility, genetics alone has little explanatory 
power over population differences in incidence of diseases (Rose, 1985). Marmot (2001), argues that many causes of diseases are social and political, and looking only at differences between individuals often misses the point that major differences in the incidence of maladies occur between populations. Considering the impact of the social factors on disease occurrence, in March 2005, the World Health Organization created the Commission on Social Determinants of Health (CSDH), with the objective of making the world aware of the importance of social determinants in the health situation of individuals and populations, and the need to combat inequities in health created by social disparities (CNDSS, 2008).

According to the WHO, SDH are "the conditions in which people are born, grow, work, live, and age, and the wider set of forces and systems shaping the conditions of daily life. These forces and systems include economic policies and systems, development agendas, social norms, social policies and political systems"

(http://www.who.int/social_determinants/en/). Throughout this paper we will attempt to show how different environments and socioeconomic settings impact the health of traditional Amazonian populations, in order to call attention to the need for the implementation of public policies aimed specifically at these groups.

\section{Research Location and Populations}

Data comes from research projects developed between 2008 and 2014 in the Brazilian Amazon basin designed to provide subsidies for debates about the health of rural populations and public policies. Populations with different historic origins and socio-ecological settings are evaluated to compare how their lifestyles and body habitus are influenced by the region's Social Determinants of Health (SDH). Data collection was accomplished in areas that represent a large extent of the environmental diversity found in the Brazilian Amazon. Morán 
(1993) presents detailed description and analysis of the Amazonian ecosystems, and Dufour et al. (2016), in this issue, provide a general synthesis of the Amazon basin and its main geographic and ecological features, for this reason we will describe only the specific populations and ecosystems of interest to this research.

The Mamirauá Sustainable Development Reservation (RDSM) is located in the Municipal district of Tefé, Amazonas State (Figure 1). It was the first conservation unit of sustainable use implemented in Brazil (1990) which included the idea of environmental protection and shared administration of natural resources between users and the government (Queiroz, 2005; Moura, 2007).

According to Moura (2007):

"Mamirauá Sustainable Development Reservation (RDSM) has an area of 1,124,000 hectares, located in the confluence of the Solimões and Japurá rivers, and next to Amanã Sustainable Development Reservation (RDSA), in the Medium Solimões area, Amazonas State. It is recognized by the international conservationist organizations as the largest floodplain protection reservation of the world" (pg. 28).

According to J. M. Ayres (1954-2003), biologist and creator of the proposal for the sustainable development reservation, the RDSM was created to reconcile the traditional mode of occupation of the Amazonian floodplain (Várzea) with the environmental conservation practices and possibilities of providing better living conditions to local populations.

A recent census counted a total of 492 houses in the RDSM (IDSM, 2013). The population is divided into small communities with sometimes 4-5, and up to 30-40 houses, usually scattered along the margins of the main rivers of the region. As in other riverine areas, the exact number of communities is difficult to specify because they split frequently and new 
ones are created while the old ones are abandoned for several reasons such as religious differences among residents, family fights, and environmental circumstances such as insect infestations, changes in the floodplain geomorphology, or shifts in river and lake courses (Moura, 2007).

The RDSM is located in a region characterised by extended periods of alternation between floods and dryness, and it is an extremely diverse environment in terms of biodiversity. The annual floods bring giant amounts of sediments from the Andes which create a rich environment responsible for the high biomass productivity of the Amazonian floodplains. The alternation of wet and dry periods defines the geomorphology of the area, the abundance and endemicity of flora and fauna, and even the patterns of human occupation (Queiroz, 2005; Moura et al., 2016). Human and animal activities are driven by the rhythm of the waters and the seasonal variations. The alternation of periods determines access to resources and transit in the Reservation. During the raining/flooding period there is more abundance of fish, and the duration of transportation between different locations and in the direction of the urban centres is reduced. In the dry period everything is more difficult, from access to clean water and food to the movement between houses and the cities (Moura, 2007).

The current occupation of the Mamirauá region began in the 19th century by people migrating from the northeast of Brazil during the Rubber Boom. The migrants integrated with local native populations and became today's caboclos or ribeirinhos (Lyma-Ayres, 1992; Queiroz, 2005). The term caboclo has many meanings and connotations (see Lima-Ayres, 1992; Silva, 2001; Rodrigues, 2006). In this paper we adopt the concept presented in Silva and Eckhardt (1994) where caboclo are tri-hybrid populations with European, African, and Amerindian ancestry living mainly in the rural areas of the Brazilian Amazon.

The participant samples from the RDSM include 76 men and 73 women; all adults $(\geq$ 18 years) and residents of $78 \%$ of the homes of eight communities representative of the socio- 
environmental diversity of that conservation unit. Data were obtained in a study to identify health and ecosystemic indicators of the Amazonian floodplain, involving about 550 residents of 88 houses of those localities (Moura, 2008).

The Caxiuanã riverine/caboclo groups live in and around the Caxiuanã National Forest (FLONA), a protected area of 330,000 hectares covered mainly by upland (terra firme) tropical forests, located in the municipal district of Melgaço, Pará State, about $400 \mathrm{~km}$ from Belém, the State's Capital (Figure 1). The FLONA is composed mainly of primary tropical rain forest (85\%), flooded forests (12\%), secondary vegetation and non-forested areas $(3 \%)$. This protected area belongs to a black water river system with relatively acidic $\mathrm{pH}$ in the Caxiuanã bay, and the daily tides have little influence on water level (MPEG, 1994).

In Caxiuanã, houses are dispersed throughout the FLONA in clusters varying from 2 to 10 homes, but some families live in isolation, in houses that are from 500 metres to 5 or more kilometres away from one another. A total of 148 individuals were investigated (72 men and 76 women), representing about $65 \%$ of the adult population resident in the area.

Mamirauá and Caxiuanã exemplify traditional rural populations as they originated from and have lived in Amazonia since the middle of the $19^{\text {th }}$ Century. They are descendants of the encounter of Amerindians with European settlers, and of Africans brought to Brazil as slaves, but who sometimes escaped from urban centres and farms to distant places in the jungle (Lima-Ayres, 1992; Silva, 2001). They have lifestyles strongly dependent on subsistence activities such as agriculture of manioc (Manihot esculenta) and beans and corn, artisanal fishery for domestic consumption and sale, collection of forest products for consumption and sale in the local towns, and small animal husbandry. They also maintain regular contacts with regional markets and participate in temporary jobs in the ecotourism activities and provide support to scientific research (Filgueiras and Silva, 2013; Lisboa et al., 2013; Moura, 2007, 2010; Piperata, 2007; Piperata et al., 2011, 2013; Silva, 2001, 2011; 
Silveira et al., 2013). In the last decade, these groups have also benefited from several social programs of the federal government, such as retirements and rural pensions, and Bolsa Família (a federal welfare program); the impact of these programs on health has not yet been fully evaluated (Brasil, 2009, 2010; Ivanova and Piperata 2010; Moura, 2007; Piperata et al., $2011 ; 2013)$. The main differences between the two protected areas are related to their ecological and political settings. The first is in a floodplain ecosystem and it was intended that the local communities would be involved in its management, with total access to the natural resources, and the latter is mainly a forestlupland ecosystem, legally a national protected area, where the families are considered intruders and their access to the local resources is formally limited.

Quilombos are groups formed predominantly by African-derived populations originated in Brazil from slave escapees who survived in the Amazon basin and other regions, making use of common systems of land ownership and tenure (Arruti, 2008; Salles, 2005; Treccani, 2006). Although there are no specific genetic studies yet of the groups discussed in this study, in general, quilombolas of Amazonia also present, in varied percentages, biological and cultural influences of Amerindian and European groups (Guerreiro et al., 1994, 1999; Santos, et al., 2008). Even though there is great variation among communities, the rural quilombolas are organised in settlements varying from 5, 6 to two dozen or more houses close to each other, usually ordered in a linear way and near to rivers and other water sources. They practice mainly subsistence agriculture, fishing, extraction of natural products, production of handicrafts for sale, and small animal husbandry for survival (Brasil, 2007b; Oliveira, 2011). In recent years the quilombolas also started to receive the Bolsa Família, which became an important source of cash to many families (Oliveira, 2011; Guimarães and Silva, 2015).

Overall 351 people (154 men and 197 women) from five quilombola communities: Africa, Laranjituba, Santo Antonio, Mangueiras, and Mola, all in the State of Pará, were 
included in this analysis, encompassing at least $60 \%$ of the adults ( $\geq 18$ years of age) in the participant communities (Figure 1). The investigated quilombo residents have subsistence patterns and socioeconomic situations similar to the riverine/caboclo groups, except that they are located predominantly in areas of upland, closer to the largest regional urban centre (Belém), and some of them have better access to basic infrastructure such as proximity to highways, electricity, health centres, telephones and primary schools, although they suffer constant discrimination due to their assumed slave ancestry (Cavalcante, 2011; Pinho et al., 2013).

Quilombolas are included in this study because they encompass a large segment of the rural Amazonian populations and hence increase the diversity and range of the sample investigated, and because politically they are in the same situation of social and environmental vulnerability as the riverine/caboclo groups, being subject to most of the same SDH factors. From a biological point of view, differences among the investigated populations are possibly smaller than the similarities because of the historical origin of the participant quilombolas.

Other information about the ecologic situation, history, geography, social and economic conditions, subsistence and health aspects of the groups and investigated areas are available in previous publications (Borges, 2011; Cavalcante, 2011; Filgueiras and Silva, 2013; Guimarães and Silva, 2015; Lisboa et al., 2013; Melo and Silva, 2015; Moura, 2007, 2008; Moura et al., 2016; Pinho et al., 2013; Piperata and Dufour, 2007; Piperata et al., 2011, 2013; Silva, 2002, 2009, 2011; Silva and Padez, 2010; Silva et al., 2006; Silveira et al., 2013). 
Figure 1. Location of the studied riverine/caboclo and quilombola areas.

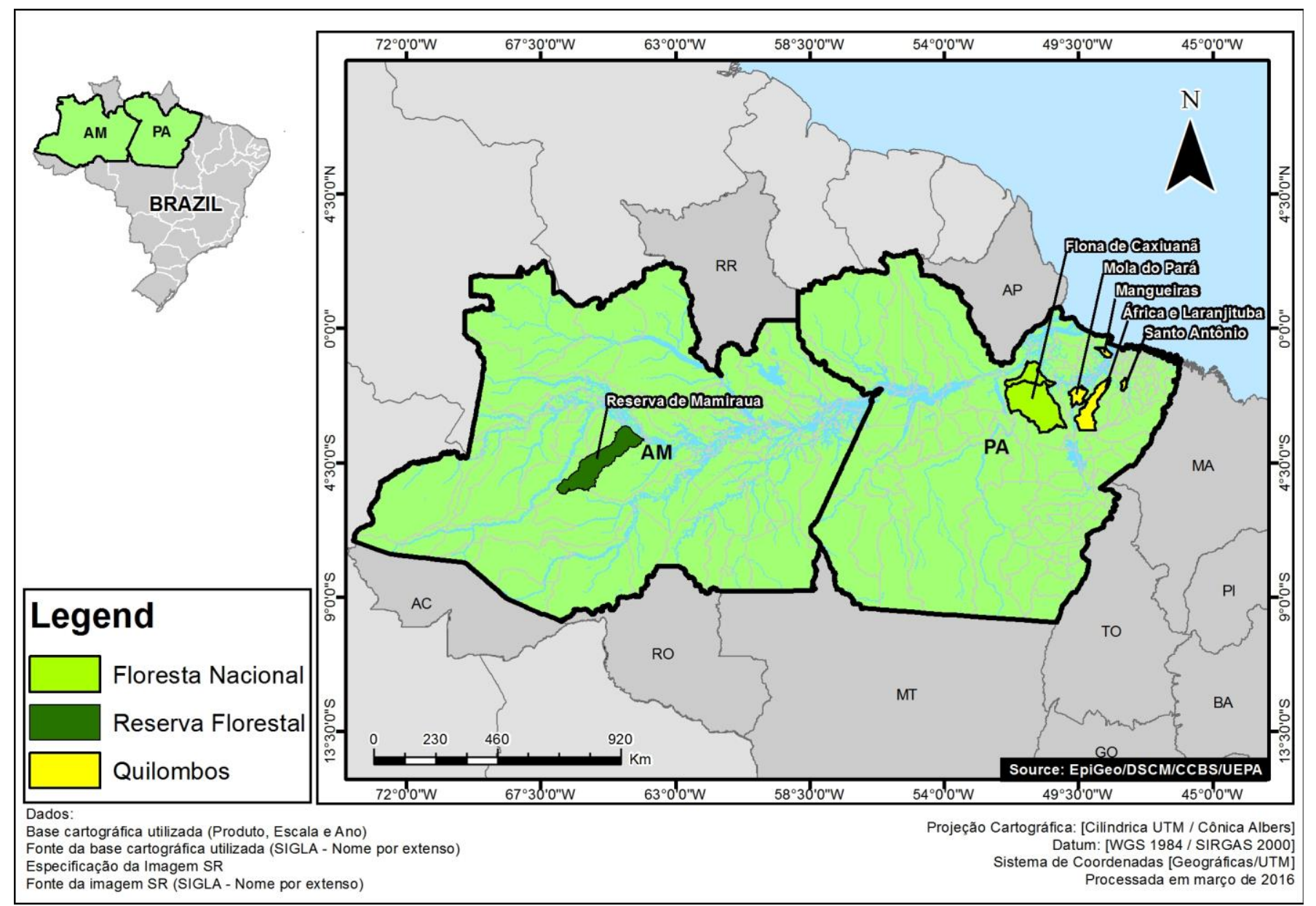

Source: EpiGeo/DSCM/CCBS/UEPA, Pará, Brazil, March, 2016.

\section{Methods}

All the projects were approved by the institutional Committee of Ethics in Research and the communities involved. All participants signed a research consent form following the Resolutions CNS/Brazil 196/96 and 466/12 (Brasil, 2012).

In all groups investigated, sampling strategy involved a first contact with the communities to explain the research objectives, obtain their group approval for participation and conduct a first population survey. This was followed by one or more field trips where individual consent was obtained, and personal (including health and anthropometric), family 
and household information was collected at each home of the locality or, according to the desire of the community and the time frame for data collection, at a central place, such as a community health centre or school, to where the families converged at a certain date and time previously defined. This research design, adapted from Silva (2001) and Moura (2007), made it possible to guarantee a high rate of participation of adults and children and men and women, representative of the overall population of each study area.

The anthropometric measures were taken following procedures described by Weiner and Lourie (1981) and SISVAN (2008). The anthropometric measurements were done by the same individuals to reduce inter-observer error.

The anthropometric variables analysed include height, weight, arm circumference, waist and hip circumferences, and triceps, subscapular and subprailiac skinfolds. Body Mass Index (BMI) was generated from the weights and heights (WHO, 2011; Deurenberg et al., 1990. Martínez et al., 1993). Circumference measures were taken with a fabric anthropometric tape, following protocols of the World Health Organization (2000). Skinfold measures were made with a Cescorf caliper, according to Frisancho (1999). The parameters adopted are described in Table 1.

Table 1: BMI and Subscapular/Tricipital Skinfolds Index (STI) parameters used for adults.

\begin{tabular}{|c|c|c|}
\hline Parameters & Overweight & Obesity \\
\hline BMI & $25.0-29.9 \mathrm{Kg} / \mathrm{m} 2$ & $30.0 \mathrm{Kg} / \mathrm{m}^{2}$ \\
\hline Subscapular/Tricipital Skinfolds Index (STI) & 0.76 and $0.99^{*}$ & $\geq 1^{* *}$ \\
\hline
\end{tabular}

$*$ High risk of central adiposity distribution. ** Indicator of abdominal obesity.

The percentage of general adiposity and the amount of fat free mass were calculated from the skinfolds according to Durnim and Womersley (1974).

The anthropometric measures were compared among sexes through an analysis of variance (oneway ANOVA) and the differences considered statistically significant at $p<0.05$. To analyse differences among populations a covariance analysis (ANCOVA) was performed 
in which the age effect was adjusted. Statistical analyses were performed using the SPSS® version 17.0.

General health evaluation was made through a clinical exam accomplished by a physician. Blood pressure was checked in the brachial artery on the left side, using a certified aneroid sphygmomanometer following procedures recommended by the Brazilian Health Ministry (Brasil, 2006) which follows the WHO parameters.

The parameter values for blood pressure assessment according to the Brazilian Health Ministry (Brasil, 2006) are presented in Table 2.

Table 2: Classification of the blood pressure in adults, according to the Brazilian Health Ministry.

\begin{tabular}{|c|c|c|}
\hline Classification & $\begin{array}{c}\text { Systolic Blood Pressure } \\
(\mathbf{m m h})\end{array}$ & $\begin{array}{c}\text { Diastolic Blood Pressure } \\
\text { (mmhg) }\end{array}$ \\
\hline Normal & $<120$ & $<80$ \\
\hline Pre-hypertension & $120-139$ & $80-89$ \\
\hline$*$ SAH & $\geq 140 \mathrm{mmH}$ & $\geq 90$ \\
\hline
\end{tabular}

Source: Brasil, 2006. *SAH - Systemic Arterial Hypertension

Systemic Arterial Hypertension ( $\mathrm{SAH}$ ) is characterised as "systolic blood pressure higher or equal to $140 \mathrm{mmHg}$ and diastolic blood pressure higher or equal to $90 \mathrm{mmHg}$ in individuals not making use of anti-hypertensive medication" (Brasil, 2006, p.14). Individuals with elevated blood pressure, between $120-139 \mathrm{mmHg}$ of systolic and $80-89 \mathrm{mmHg}$ of diastolic, tend to maintain pressure above the population average and they are potentially at higher risk of developing SAH and associated cardiovascular events being considered in a stage of "pre-hypertension" (Brasil, 2006).

Information about the situation of environmental risks, labour activities, subsistence strategies, life and housing conditions and geographic/land/social conflicts were also obtained through participant observation and interviews as part of the SDH assessment. 


\section{Results}

The studied communities have a diverse set of economic and subsistence activities, from agriculture for domestic consumption and sale, artisanal fishery, small animal husbandry, forest management, handicraft manufacture and ecotourism, to formal work as teachers, health agents and municipal technicians. This range of activities is similar to other Amazonian rural populations (Brasil, 2007b, 2008; Guerrero, 2010; Lima-Ayres, 1992; Moura, 2007, 2010; Murrieta, 1994; Murrieta and Dufour, 2004; Nugent, 1993; Piperata and Dufour, 2007). In the last decade an important cash contribution from income distribution programs of the federal government (Bolsa Família) has been given to riverine and quilombola families. Together with rural retirement pensions and temporary contracts of work, these have increased their access to consumer goods and affected their diet (Ivanova and Piperata, 2010; Moura, 2007; Pinho et al., 2013; Piperata et al., 2011, 2013; Silva, 2011). The investigated communities live in different ecological environments and, due to the historical combination of the main groups that contributed biologically and culturally to the formation of the current Amazonian population (Amerindians, Europeans and Africans), they represent a significant portion of the regional biocultural diversity for which information about health, nutrition, and the SDH is still very limited.

All communities present precarious conditions of environmental sanitation, lacking basic sanitary infrastructure and piped water, and have difficult housing situations, with most buildings made of wood, with a small number of rooms, and many of them without an internal water closet, which relates directly to high intestinal parasite loads and other infectious and deficiency diseases found among these groups (Giatti et al., 2007; Lisboa et al., 2013; Moura, 2007, 2008; Pinho et al., 2013; Silva, 2001; 2009). Social and economic activities developed in the rural areas of Amazonia, mainly in the floodplain, are strongly marked by seasonality 
(flood and reduction of the water levels), which directly influences the life rhythm and affects access to health and education, increasing the difficulty of reaching the health centres and schools during some periods of the year (Filgueiras and Silva, 2013; Moura, 2007; Silva, 2001; 2006, 2011; Silva et al., 2006).

The sociodemographic situation of these populations is presented in Table 3. Caboclos and quilombolas show similar socioeconomic conditions, particularly in relation to education, income and number of rooms in the house. However, some particularities were noticed such as: more accessldependence on government programs among quilombolas, likely related to a closer political proximity with the urban centres and better social organisation in associations; more consumer goods in Mamirauá, due to the several projects generated by the Mamirauá Institute throughout the years and access to cheaper goods from the "Zona Franca de Manaus" (Manaus Free Trade Zone); and more residents in the houses in Caxiuanã, due to the legislation of the FLONA that limits the expansion of new families. The difference in the frequency of kitchens inside or outside the houses is associated with the habits of the riverine populations who traditionally maintain their "girau" outside the house to facilitate food processing, mainly fish, and the drainage of waste water. The quilombolas prefer the kitchen inside the house, especially if there is a faucet with water pumped from an open well with an electric engine, which indicates higher social status. Among quilombolas, over $80 \%$ of the houses have access to electricity while less than $20 \%$ of houses among the riverine do. The high number of latrines out of the house in all groups, usually wholes dug directly in the ground, indicates the lack of access to environmental sanitation and potential contamination of the populations and water sources by fecal materials.

Table 3. Selected sociodemographic characteristics of the three Amazonian groups.

\begin{tabular}{|l|c|c|c|}
\hline & Quilombos & Mamirauá & Caxiuanã \\
\hline & $\%$ & $\%$ & $\%$ \\
\hline Formal Education & & & \\
\hline $0-4$ years & 76.8 & 74 & 78.2 \\
\hline
\end{tabular}




\begin{tabular}{|c|c|c|c|}
\hline$>4$ years & 23.2 & 26 & 21.8 \\
\hline \multicolumn{4}{|l|}{ Income per house } \\
\hline$<1$ minimum wage* & 42.3 & 37 & 51.5 \\
\hline 1 to 2 minimum wage & 50.5 & 58 & 39.2 \\
\hline$>2$ minimum wage & 7.2 & 5 & 9.3 \\
\hline \multicolumn{4}{|c|}{ Government support*** } \\
\hline Yes & 62.5 & 27 & 35.0 \\
\hline No & 37.5 & 73 & 65.0 \\
\hline \multicolumn{4}{|c|}{ Consumer goods per house**** } \\
\hline $1-3$ & 11.1 & 27 & 50.2 \\
\hline $4-6$ & 78.0 & 46 & 35.3 \\
\hline $7+$ & 10.9 & 27 & 14.5 \\
\hline \multicolumn{4}{|l|}{ No. of rooms per house } \\
\hline 1 & 7.2 & 16 & 3.9 \\
\hline 2 & 23.7 & 24 & 38.5 \\
\hline 3 & 23.3 & 38 & 53.8 \\
\hline $4+$ & 45.8 & 22 & 3.8 \\
\hline \multicolumn{4}{|l|}{ No. of people per house } \\
\hline $1-5$ & 67.1 & 50 & 33.3 \\
\hline $6-10$ & 31.4 & 39 & 51.4 \\
\hline$>10$ & 1.5 & 11 & 15.3 \\
\hline \multicolumn{4}{|c|}{ Kitchen inside the house } \\
\hline Yes & 96.2 & 0 & 69.2 \\
\hline No & 3.8 & 100 & 30.8 \\
\hline \multicolumn{4}{|c|}{ Latrine inside the house } \\
\hline Yes & 55.2 & 0 & 15.1 \\
\hline No & 44.8 & 100 & 84.9 \\
\hline
\end{tabular}

$* 1$ minimum wage $=$ Approximately U\$250.00 as of march, 2010 .

** Includes Bolsa Família, retirement pensions, rural pensions and other support provided by the governments in the form of cash.

*** Includes items such as motorboat, boat engine, gas stove, radio, TV, parabolic antenna, stereo, DVD player, bicycle, chainsaw, clock, sofa, sewing machine, washing machine, shotgun, mattress, electricity generator.

In Table 4 the median values of BMI, adiposity percentage, amount of fat free mass and the subscapular/triceps index (STI) after adjusting for the age effect are described. In the quilombolas all variables present significant differences among the two sexes, except the upper arm circumference (UAC) and the waist. The three groups present a similar pattern in 
which men have significantly higher values in height, weight, fat free mass and STI, and women have significantly higher values of skinfolds, adiposity percentage and waist and hip circumferences, except in the population of Caxiuanã where men present a mean value of waist circumference significantly higher than women. Comparing the three groups (F1), quilombola men are significantly taller than men from Caxiuanã and Mamirauá. Mamirauá men have significantly higher adiposity values (skinfolds) and percentage of general adiposity, hip perimeter and amount of fat free mass. In all groups, women present statistically significant differences (F2) in several variables: Mamirauá women present height, waist and hip circumferences and STI superior to the quilombolas and Caxiuanã women. The quilombola women present general adiposity values higher than Caxiuanã and Mamirauá women.

Insert Table 4

Figures 2 and 3 present the obesity values (including overweight) according to WHO intervals in men and women of the different age groups. As the study samples are small because Amazonian rural populations' settlements characteristically have a small total size, we evaluated overweight together with obesity as both are correlated with the elevation of morbidity and mortality rates (Hu, 2008; SISVAN, 2008). In men, in all age groups, the Mamirauá population presents higher values than the quilombola and Caxiuanã. Caxiuanã men present lower values than quilombolas and Mamirauá males, except in the 60-75 year-old age group (Figure 2). In women, the quilombola sample presents higher values than Caxiuanã and Mamirauá in all age groups, except the 18-29 and 50-59 years (Figure 3). In all age groups, Caxiuanã women present less overweight/obesity than quilombola and Mamirauá females. 
Insert Figures 2 and 3

The frequency of blood pressure status in the studied populations is shown in Table 5.

SAH is more frequent among the quilombola men and women; Caxiuanã men have more systolic and diastolic pre-hypertension than the other men, and Mamirauá women have a higher frequency of systolic pre-hypertension than everyone even though this group presents the overall lower frequency of SAH.

Table 5: Characterisation of the three studied populations of the Amazon region according to the blood pressure status and sex $(n=646)$.

\begin{tabular}{c|cc|cc|cc}
\hline & \multicolumn{2}{|c|}{ Quilombola } & \multicolumn{2}{c|}{ Caxiuanã } & \multicolumn{2}{c}{ Mamirauá } \\
\cline { 2 - 7 } & $0 \%$ & $0 \%$ & $0 \%$ & $\delta \%$ & $0 \%$ & $0 \%$ \\
\hline $\begin{array}{c}\text { Systolic Pre- } \\
\text { Hypertension } \\
\text { Systolic }\end{array}$ & 30.7 & 30 & 36.7 & 35.6 & 21.5 & 41.5 \\
$\begin{array}{c}\text { Hypertension } \\
\text { Diastolic Pre- }\end{array}$ & 23.6 & 18.3 & 13.9 & 17.8 & 6.2 & 7.7 \\
$\begin{array}{c}\text { Hypertension } \\
\text { Diastolic }\end{array}$ & 22.9 & 21.7 & 29.1 & 26.0 & 15.4 & 20.0 \\
$\begin{array}{c}\text { Hypertension } \\
* \text { SAH }\end{array}$ & 27.9 & 18.3 & 12.7 & 13.7 & 7.7 & 9.2 \\
\hline
\end{tabular}

*SAH - Systemic Arterial Hypertension

\section{Discussion}

Obesity, arterial hypertension and type 2 diabetes are among the chronic-degenerative diseases of larger demographic, economic and social impact nowadays (Hu, 2008; SISVAN, 2008; SBEM, 2010; SBH, 2010). Several studies have shown that the prevalence of obesity, hypertension and diseases associated with them varies among populations depending on their degree of contact with the Western culture, socio-ecological situation, impact of the market economy and government policies on their diet and lifestyle and, perhaps, their biological ancestry (Blanes, 2008; Dressler, 1999; Liebert et al., 2013; Silva, 2001, 2011). According to the Brazilian Commission on the Social Determinants of Health, SDH are the social, 
economic, cultural, racial/ethnic, psychological and behavioural factors that influence the occurrence of health problems and the risk factors in a population (CNDSS, 2008).

Nutritional and cardiovascular diseases are known to be associated with all these factors, hence, by using a SDH perspective it is possible to look for the causes of the causes of these diseases and propose more adequate public policies to deal with them.

In Brazil, most of the epidemiologic studies of non-transmissible chronic diseases have been concentrated in urban areas and in the South and Southeastern regions. There are only a relatively limited number of studies in the North, and those accomplished among rural populations are few (Adams, 2002; Alencar et al., 1999; Borges, 2011; Borges and Silva, 2010; Giugliano et al., 1981; Melo and Silva, 2015; Pinho et al.; 2013; Silva, 2004b, 2006, 2009, 2011). More studies are still needed to understand the situation and distribution patterns of the "diseases of modernity" (hypertension, type 2 diabetes, obesity, metabolic syndrome, among others), and to identify the biological, environmental and social factors that determine the risk dynamics in these populations.

Several investigations have shown that there is a relationship between infant malnutrition and overweightlobesity and their associated diseases in adult life (Bogin, 2010; $\mathrm{Hu}, 2008$; Popkin, 2003). Recent long term studies among native Americans such as the Shuar and the Tsimane' have also shown that the impacts of socio-economic changes on health in traditional populations can be fast and dramatic, although varied in level according to a number of factors (Rosinger et al., 2013; Liebert et al., 2013; Urlacher et al., 2016 in this volume). Research among caboclo and quilombola populations have already demonstrated high percentages of infant malnutrition and the epidemiologic transition in these groups (Brasil, 2007b; Lahr, 1994; Oliveira, 2011; Silva, 2001, 2009; Silva and Guimarães, 2015). As has been established in other developing countries, the results presented here highlight that more than any single biological factor, there is a direct relationship between the situation of 
socio-ecological vulnerability and the populations' health in relation to both infectiousparasitic as well as chronic non-transmissible diseases.

Both overweight and obesity prevalence in the studied populations is high, especially in men from Mamirauá and in quilombola women, while low weight $\left(\mathrm{BMI}<18.5 \mathrm{Kg} / \mathrm{m}^{2}\right)$ is not significant in either men or women. Compared to other Brazilian populations (Brasil, 2009; Blanes, 2008; CNDSS, 2008; IBGE, 2010), men from Mamirauá present very high frequencies of overweight/obesity (51.3\%), only lower than the Brazilian urban population (53.5\%), while men from Caxiuanã present the lowest values $(13.3 \%)$. On the other hand, quilombola women present values (53.4\%) as high as the general population of women of the country $(53.1 \%)$, including from urban $(53.1 \%)$ and rural $(53.4 \%)$ areas separately. Women from Caxiuanã present lower values (26.3\%) compared to other Brazilian groups.

From a cultural point of view, among Amazonian rural populations who are used to food insecurity and all types of infrastructure deficiencies, there is a widespread perception that fat is healthy and that being a "chubby" child or adult is an indicator of good life quality. According to $\mathrm{Hu}(2008)$ the different perceptions among populations of the meaning of being "fat" (the African-Americans in the USA, or the Samoans, for instance), creates in some groups a higher social tolerance to people with overweight and obesity as these are not seen as potentially sick. In the investigated groups, overweight is not considered a risk for diseases but a sign of health and that the family has financial resources and high social status, demonstrating the need to understand the socio-cultural dynamics when investigating the epidemiologic situation of these populations.

Besides eating, physical activity is one of the decisive factors in weight maintenance and gain (Hu, 2008). The differential patterns of physical activity and eating habits between men and women traditionally present in the rural populations, the current reduction in women's physical activity as a function of a smaller number of children, the acquisition of 
industrialised and frozen foods that require little processing for preparation, and consumer goods such as gas stove, television, DVD player and washing machines, may have an important role in the differences observed in the frequency of obesityloverweight and hypertension among the investigated groups. As gender roles, work, and daily activities are important SDH, more detailed research at the home level is necessary to elucidate the impact of the new consumption patterns on the health of the Amazonian rural populations, particularly the women.

In relation to blood pressure, the prevalence of SAH is higher in the quilombola population than in Caxiuanã and Mamirauá (Table 5). The overall pre-hypertension prevalence and SAH are correlated with the overweight/obesity patterns and are of particular concern among the women, who are an especially vulnerable segment of the rural populations (Brasil, 2009; Borges and Silva, 2010; Borges, 2011; Paixão and Carvalho, 2008; Silva, 2001). Although the prevalence of SAH is not above that observed in other Brazilian rural and urban populations (Brasil, 2006; Silva et al, 2006), the values show that hypertension is already a public health problem among these Amazonian rural populations.

There are still few investigations of SAH prevalence in the non-indigenous inhabitants of the rural areas of Northern Brazil and the direct comparison with other studies is difficult, as different works usually use populations with higher age groups ( $\geq 19$ years old at least), while for this study individuals from 18 years old were considered. In a general analysis, it is possible to notice that although the overall prevalence observed here is not above what has been reported elsewhere, when the high pre-hypertension and the isolated systolic or diastolic hypertension prevalence in the three groups are also taken into consideration, added to their overweight/obesity situation and the socio-ecological precariousness in which they live, a complex picture arises which combines epidemiologic and nutritional transitions, reflecting 
the importance of the social determinants in the rural populations' health, and requiring immediate action to avoid an SAH epidemic and its accompanying chronic manifestations.

Generally, groups exposed to greater influence of the Western culture and those more involved with market economy present higher obesity and SAH levels, and a stronger association between blood pressure and chronological age (Dressler, 1999; $\mathrm{Hu}, 2008$; Rosinger et al., 2013; Silva et al., 1995). Although these effects have been observed independently of the place the populations inhabit, the association patterns and environmental factors that contribute to the elevation of blood pressure, and the obesity levels as well, with age and ancestry have been shown to be highly variable as a consequence of the economic, ecologic, historic-cultural and biological factors of each population (Dressler, 1999; Wirsing, 1985), characterising a strong relation among the socio-ecological situation - the Social and Environmental Determinants (Blanes, 2008, SBEM, 2010; SCDH, 2005) - and the health/illness of the investigated populations.

Among the riverine/caboclo and the quilombola, the difficulties related to access to potable water, environmental sanitation, and health services, although they have improved in some areas, especially Mamirauá, in the last years (Moura, 2007, 2008; Moura et al., 2016), are still a matter of concern as they are involved with the origin of many diseases such as diarrhoeas, anaemia, and infant malnutrition and death, which are among the main morbidity factors related to the SDH in the Amazon region (Brasil, 2008, 2009; CNDSS, 2008; Lahr, 1994; Moura, 2008; Piperata et al., 2013; Silva, 2009).

Although Brazil has gone through several economic and social turbulences in the last 50 years, an accelerated process of nutritional transition is underway, which has increased overweight/obesity prevalence (and also SAH), mainly among women, while still maintaining high, although falling, malnutrition prevalence, mainly infantile (Brasil, 2009, 2010; CNDSS, 2008; Ivanova and Piperata, 2010; Piperata et al., 2011). This puts rural Amazonian 
populations, such as the riverine and quilombolas, in the vulnerable situation of having a double burden of disease, characterising the epidemiologic transition taking place in the country, and particularly in Amazonia (CNDSS, 2008; Monteiro et al., 2010; Oliveira, 2010; Silva, 2006). In the States of the North, circulatory system diseases are currently among the main causes of death in adults, while neonatal and infant mortality continues to be among the highest in the country (Brasil, 2010; CNDSS, 2008). On the other hand, the amount of disease and death underreporting and registered as causes poorly defined make the existing statistics difficult to believe, possibly underestimating the real health situation of the region (Lisboa et al., 2013; Silva, 2006).

The population of Amazonia had the lowest Gini index in the country in 2013 (0.478) (IBGE, 2015), and the second smallest per capita income of the nation in that year (IBGE, 2015). The groups investigated here reflect that index. As in other areas of Brazil, poverty, the precariousness of environmental sanitation and of other basic infrastructure conditions, illiteracy, unemployment, and racism/discrimination affect mainly the self-declared "pardo and negro" (brown and black) and the poorer rural segments of the population (CNDSS, 2008; Paixão and Carvalho, 2008; Pinho et al., 2013), where the quilombolas and the riverine/caboclo can be included, further characterising their socio-ecological vulnerability.

Studies indicate that in Northern Brazil obesity affects the poorest and lower educated population mostly, and mainly women; in some rural populations SAH prevalence is higher among them as well, and there is higher mortality among black and brown women due to circulatory diseases (CNDSS, 2008; Oliveira, 2011; Silva et al., 2006). However, as there is limited data on SAH or obesity prevalence in rural populations, their true impact on the several vulnerable groups of Amazonia are still ignored. The investigated populations fit in all the social and environmental vulnerability descriptors, making it clear that they are especially 
vulnerable to the SDH and that specific public policies ought to be implemented urgently to improve their quality of life and health.

\section{Conclusions}

There are still few studies about the human biology of riverine/caboclo and quilombola populations. This group of investigations is pioneering in the simultaneous interdisciplinary study of the morbidity situation for chronic diseases and the SDH of these combined populations.

It was identified that, overall, the precarious socio-ecological situation in which the studied populations live exposes them to a double burden of disease. The Caxiuanã population, more isolated physically, with less access to financial resources and more precarious infrastructure, present the shortest and thinnest individuals, and intermediate pre and SAH levels compared to quilombolas and Mamirauá. Quilombola men are taller and the women present higher overweightlobesity prevalence; both men and women have higher pre and SAH prevalence among the three populations. Mamirauá women are the tallest, the men have higher overweightlobesity and there is smaller pre and SAH prevalence in general.

The differences observed among the groups can be attributed to factors such as psycho-social stress (racism/discrimination); cultural behavioural patterns; more access to cash and the proximity to urban centres found among the quilombolas; the intense work of the Mamirauá Institute for Sustainable Development to improve infra-structure, the epidemiologic, and the income situation of the resident families in Mamirauá; and to the particularly precarious conditions of survival, sanitation, health in general, and almost total absence of the State in Caxiuanã. Overall, there is a strong connection between what has been defined as the SDH and the epidemiologic situation of these groups. 
Further studies in these and other populations using an SDH framework will contribute to the proposition of future measures seeking to reduce the double burden of disease associated with the epidemiologic transition, and prevent, among the Amazonian rural populations, the high mortality rates due to cardiovascular disorders observed in the urban areas.

In the development of our projects, dialogue with the communities, the local health and education professionals, and the researchers has been prioritised. This is to promote knowledge exchange and local empowerment as the riverine and quilombolas have been historically kept out of national public policies. These research endeavours also motivated discussion with community and municipal health managers about their health knowledge and needs, contributing to public policy planning aimed specifically to them (Silva, 2015). We believe the information presented here can also be of use to policy planners elsewhere throughout the Amazon basin, where some of the world's most vulnerable rural populations survive in different countries and are exposed to similar problems.

\section{Funding}

MCT/CNPq/MS-SCTIE-DECIT, Brazil, Procs. Nº 409598/2006-2, 409794/2006-6, 403224/2005-0, and PPSUS/MS-DECIT/CNPq/SESPA/FAPESPA, Brazil, Edital FAPESPA 011/2-013, ICAAF 076/2013.

\section{Acknowledgements}

To MCT/CNPq/MS-SCTIE-DECIT, Brazil, Procs. N 409598/2006-2, 409794/2006-6, and 403224/2005-0. To the contributions of Profa. Dra. Jane F. Beltrão (UFPA), Profa. Dra. Maria das Graças Ferraz (MPEG), Profa. Dra. Jacqueline Serra-Freire (UNILAB), Prof. Dr. 
Nelson Veiga (UEPA), William Borges, Inara Cavalcante, Mayco Emmanuel, and Roseane

Bittencourt. To the support of the Universidade Federal do Rio de Janeiro/National

Museum/Biological Anthropology Section, Museu Paraense Emílio Goeldi, Scientific Station

"Ferreira Penna", UNICEF, Universidade Federal do Pará, and EpiGeo/DSCM/CCBS/UEPA.

We also thank the riverine and quilombola populations who participated of the studies. 


\section{Bibliography}

Adams C. 2002. Estratégias adaptativas de duas populações caboclas (Pará) aos ecossistemas de várzea estuarina e estacional: Uma análise comparativa. $\mathrm{PhD}$ Thesis, Department of Ecology, Universidade de São Paulo, São Paulo.

Adams C, Murrieta RSS, Neves W (Eds.). 2006. Sociedades Caboclas Amazônicas: Modernidade e invisibilidade. São Paulo: Annablume.

Alencar FH, Yuyama LKO, Nagahama D, Parente RCP. 1999. Estudo antropométrico de pré-escolares da Calha do Rio Negro. Amazonas, Brasil. II Barcelos. Acta Amaz, 29:293302.

Arruti M. 2008. Quilombos. In: Pinho O. (Org). Raça: Novas Perspectivas Antropológicas. ABA/Ed. Unicamp/EDUFBA: Campinas, p. 315-350.

Blanes AC. 2008. Susceptibilidade genética e outros fatores de risco associados ao sobrepeso e à obesidade em populações afro-descendentes do Vale do Ribeira-SP. Doctoral Dissertation, Instituto de Ciências Biológicas. São Paulo: Universidade de São Paulo.

Borges WD. 2011. Prevalência da hipertensão arterial sistêmica e seus determinantes bioantropológicos em populações quilombolas da Amazônia. Master Thesis, Programa de Pós-Graduação em Saúde, Sociedade e Endemias na Amazônia, Belém: Universidade Federal do Pará/Universidade Federal do Amazonas/Centro de Pesquisa Leônidas \& Maria Deane - Fundação Oswaldo Cruz.

Bogin, B. 2010. The Maya in Disneyland: Child growth as a marker of nutritional, economic, and political ecology. In: Dufour DL, Goodman AH, Pelto G (Eds). Nutritional Anthropology: Biocultural Perspectives on Food and Nutrition. 2.Ed., Oxford: Oxford University Press, pp. 231-244.

Borges WB, Silva HP. 2010. Prevalência de hipertensão arterial sistêmica em populações quilombolas da Amazônia: Reflexões a luz da antropologia biológica. In: XI Congresso da Associação Latino-Americana de Antropologia Biológica. Bogotá: Universidad Nacional de Colômbia (CD-ROM).

Brasil. 2006. Hipertensão arterial sistêmica para o Sistema Único de Saúde (Cadernos de Atenção Básica; 16) (Série A. Normas e Manuais Técnicos). Ministério da Saúde, Secretaria de Atenção à Saúde, Departamento de Atenção Básica. Brasília: Ministério da Saúde.

Brasil. 2007a. Decreto 6040, de 7/2/07. Política Nacional de Desenvolvimento Sustentável dos Povos e Comunidades Tradicionais. Brasília: DOU.

Brasil. 2007b. Chamada Nutricional Quilombola 2006 - Sumário Executivo. Ministério do Desenvolvimentos Social e Combate a Fome, Secretaria de Avaliação e Gestão da Informação, Departamento de Avaliação e Monitoramento, Brasília-DF.

Brasil. 2007c. Programa Nacional de Saúde Integral da População Negra. Ministério da 
Saúde. Brasília-DF: Secretaria de Gestão Estratégica e Participativa (MSSGEP). Available in:

http://bvsms.saude.gov.br/bvs/publicacoes/politica_nacional_saude_populacao_negra.pdf. Access: 09/25/2014.

Brasil. 2008. Cadernos de estudos, desenvolvimento, social em debate n.9. Políticas sociais e Chamada Nutricional Quilombola: estudos sobre condições de vida nas comunidades e situação nutricional das crianças. Brasília-DF: Ministério do Desenvolvimento Social e Combate à Fome. Secretaria de Avaliação e Gestão da Informação.

Brasil. 2009. Pesquisa nacional de demografia e saúde da criança e da mulher - PNDS 2006: Dimensões do processo reprodutivo e da saúde da criança. Ministério da Saúde, Centro Brasileiro de Análise e Planejamento. Brasília-DF: Ministério da Saúde.

Brasil. 2010. Objetivos de Desenvolvimento do Milênio. Relatório nacional de acompanhamento. Secretaria de Assuntos Estratégicos da Presidência da República, Ministério do Planejamento, Orçamento e Gestão. Brasília-DF: IPEA.

Brasil. 2012. Resolução $\mathrm{N}^{\circ}$ 466, de 12 de dezembro de 2012. Available in: http://conselho.saude.gov.br/web_comissoes/conep/aquivos/resolucoes/23_out_versao_fin al_196_ENCEP2012.pdf. Access: 01/17/2016.

Cavalcante IMS. 2011. Acesso e Acessibilidade aos Serviços de Saúde em Três Quilombos na Amazônia Paraense: Um Olhar Antropológico. Master Thesis, Programa de PósGraduação em Saúde, Sociedade e Endemias na Amazônia, Belém: Universidade Federal do Pará/Universidade Federal do Amazonas/Centro de Pesquisa Leônidas \& Maria Deane Fundação Oswaldo Cruz.

CNDSS - Comissão Nacional sobre Determinantes Sociais em Saúde. 2008. As Causas Sociais das Iniqüidades em Saúde no Brasil. Relatório Final. Brasília: CNDSS.

CSDH - Commission on Social Determinants of Health. 2005. Towards a conceptual framework for analysis and action on the Social Determinants of Health. Discussion paper for the Commission on Social Determinants of Health - DRAFT. 1, July, Available at: http://www.determinants.fiocruz.br/pdf/texto/In_texto2.pdf.

Deurenberg P, Pieters JJ, Hautvast JG. 1990. The assessment of the body fat percentage by skinfold thickness measurements in childhood and young adolescents. $\mathrm{Br} J$ Nutrition, 63:293-303.

Dressler WW. 1999. Modernization, stress and blood pressure: new directions in research. Hum Biol. 71:583-605.

Dufour DL, Piperata BA, Williams DD, Wilson WM. 2016. Amazonian foods and implications for human biology. Ann Hum Biol ??:??-??.

Durnim JVGA, Womersley J. 1974. Body fat assessed from density and its estimation from skinfold thickness: measurements on 481 men and women aged from 16 to 72 years. Brit J of Nutrition, 32: 77-97. 
Filgueiras L, Silva HP. 2013. Investigação das condições de saúde e ambiente na população da Floresta Nacional de Caxiuanã, Pará, Brasil - Análises antropométricas preliminares. Áreas Protegidas e Inclusão Social: Tendências e Perspectivas, 6(1):11671176. Available in: http://sapisbh2013.com.br/normas/eixo07.pdf\#page=158

Freitas DA, Caballero AD, Marques AS, Hernández CIV, Antunes SLNO. 2011. Saúde e comunidades quilombolas: uma revisão da literatura. Rev. CEFAC, Set-Out; 13(5):937943.

Frisancho RA. 1999. Anthropometric Standards for the Assessment of Growth and Nutritional Status. Ann Arbor: Univ. Michigan Press.

Giatti LL, Silva LA, Jesus M, Nazaré MO. 2007. Relatório de identificação e quantificação de coliformes totais e termotolerantes em amostras de água de comunidades ribeirinhas na Reserva de Desenvolvimento Sustentável Mamirauá, Estado do Amazonas, Brasil. Manaus: MS, Fiocruz, IDSM.

Giugliano R, Giugliano L, Shrimpton R. 1981. Estudos nutricionais das populações rurais da Amazônia I - Várzea do Rio Solimões. Acta Amaz., 11:773-788.

Guerrero AFH. 2010. Situação nutricional de populações remanescentes de quilombos do município de Santarém, Pará - Brasil. Doctoral Thesis. Rio de Janeiro: Escola Nacional de Saúde Pública Sergio Arouca.

Guerreiro JF, Figueiredo MS, Zago MA. 1994. Beta-globin gene cluster haplotypes of Amerindian populations from the Brazilian Amazon Region. Hum. Heredity, 44: 142-149.

Guerreiro JF, Ribeiro-dos-Santos AKC, Santos EJM, Vallinoto ACR, Cayres-Vallinoto IMV, Aguiar GFS, Santos SEB. 1999. Genetical-demographic data from two Amazonian populations composed of descendants of African slaves: Pacoval and Curiau. Gen. and Mol. Biol., 22 (2): 163-166.

Gomes KO, Reis EA, Guimarães MDC, Cherchiglia ML. 2013. Utilização de serviços de saúde por população quilombola do Sudoeste da Bahia, Brasil. Cad. Saúde Pública, Rio de Janeiro, 29(9): 1829-1842.

Guimarães RCR, Silva HP. 2015. Estado nutricional e crescimento de crianças quilombolas de diferentes comunidades do Estado do Pará. Amazônica, Rev. de Antropol. (Online), 7(1):186-209.

Hu F. 2008. Obesity Epidemiology. Cambridge: Oxford University Press.

IBGE. 2010. Pesquisa de orçamentos familiares 2008-2009: Antropometria e estado nutricional de crianças, adolescentes e adultos no Brasil. Rio de Janeiro: Instituto Brasileiro de Geografia e Estatística.

IBGE. 2015. Pesquisa nacional por amostra de domicílios: síntese de indicadores 2013. 2 Ed. Rio de Janeiro: IBGE. 
IDSM (Instituto de Desenvolvimento Sustentável Mamirauá). 2013. Relatório de gestão TCU - Exercício 2013. Tefé: IDSM.

Ivanova SA, Piperata BA. 2010. Dietary intake among Ribeirinha women in the eastern Amazon: evidence of a nutrition transition? Am J Hum Biol. 22(2):257-258 (abstract).

Lahr MM. 1994. Relatório baseado na análise de dados antropométricos tomados em crianças de 0 a 10 anos na Estação Ecológica de Mamirauá - 1993. Coletânea de Relatórios das Comunidades da RDS Mamirauá, Período de 1991-1995 (Datilo). Tefé, Belém: IDSM.

Liebert MA, Snodgrass JJ, Madimenos FC, Cepon TJ, Blackwell AD, Sugiyama L.S 2013. Implications of market integration for cardiovascular and metabolic health among an indigenous Amazonian Ecuadorian population. Ann Hum Biol, 40(3): 228-242.

Lima-Ayres DM. 1992. The Social category caboclo: History, social organization, identity, and outsider's social classification of the rural population of an Amazonian Region (The Middle Solimões). Ph.D. Dissertation. Cambridge: University of Cambridge.

Lima MGM, Pereira EMB. 2007. Populações tradicionais e conflitos territoriais na Amazônia. Belo Horizonte, Geografias, 3(1): 107-119.

Lisboa PLB, Bezerra MGF, Cardoso ALR. 2013. Caxiuanã: História natural e ecologia de uma Floresta Nacional da Amazônia. Belém: MPEG.

Martínez E, Devesa M, Bacallao J, Amador M. 1993. Indice subescapular/tricipital: valores en niños y adolescentes cubanos. Arch Latinoam Nutr. 43: 199-203.

Marmot M. 2001. Economic and social determinants of disease. Bull of the W Hea Organ, 79(10): 988-989.

Melo MFT, Silva HP. 2015. Doenças crônicas e os Determinantes Sociais da Saúde em comunidades quilombolas do Pará, Amazônia, Brasil. Revista ABPN, Dossiê Saúde da População Negra, 7(16):168-189. Available in: http://www.abpn.org.br/Revista/index.php/edicoes/article/view/531

Monteiro CA, Benicio MHD, Conde WL, Konno S, Lovadino AL, Barros AJD, Victora C G. 2010. Narrowing socioeconomic inequality in child stunting: the Brazilian experience, 1974-2007. Bul. of the World. Health Org., 88:305-311.

Morán EF. 1993. Through Amazonian eyes: The human ecology of Amazonian Populations. Univ. Iowa Press: Iowa City.

Moura EAF. 2010. Comportamento reprodutivo das mulheres ribeirinhas do Amanã. Uakari, 1(1):31-40.

Moura EAF. 2007. Práticas socioambientais na Reserva de Desenvolvimento Sustentável Mamirauá Estado do Amazonas, Brasil. Doctoral Dissertation, Belém: NAEA/ Universidade Federal do Pará. 
Moura EAF. 2008. Relatório técnico parcial do projeto Indicadores Ecossistêmicos de Saúde na Várzea Amazônica. Processo No 403224/2005-0- CNPq. Belém: Instituto de Desenvolvimento Sustentável Mamirauá - IDSM.

Moura EAF, Nascimento AC, Corrêa D, Alencar E, Sousa IS. 2016. Sociodemografia da Reserva de Desenvolvimento Sustentável Mamirauá: 2001-2011. Tefé, AM: IDSM; Belém: NAEA.

MPEG (Museu Paraense Emílio Goeldi). 1994. Relatório da Estação Científica "Ferreira Penna"/ECFPn: Da concepção ao momento atual (1989/1994). Brasília: Ministério da Ciência e Tecnologia (MCT), Conselho Nacional de Desenvolvimento Científico e Tecnológico (CNPq).

Murrieta RSS. 1994. Diet and subsistence: Changes in three caboclo populations on Marajó Island, Amazonia, Brazil. Master's Thesis. Boulder: University of Colorado.

Murrieta RSS, Dufour D. 2004. Fish and farinha: protein and energy consumption in Amazonian rural communities on Ituqui Island, Brazil. Ecol. of Food and Nutrit., 43:231255.

Nugent S. Amazonian caboclo society: An essay on invisibility and peasant economy. Oxford: Berg; 1993.

Oliveira APP. 2010. Preditores da desnutrição infantil em populações ribeirinhas do Pará. Master's Thesis. Belém: Universidade Federal do Pará/Universidade Federal do Amazonas/Centro de Pesquisa Leônidas \& Maria Deane - Fundação Oswaldo Cruz.

Oliveira ASJ. 2011. Quilombolas do Pará: Condições de vulnerabilidade nas comunidades remanescentes de quilombo. Assis: Triunfal Gráfica e Editora.

Paixão M, Carvalho LM. (Orgs.) 2008. Relatório anual das desigualdades raciais no Brasil; 2007-2008. Rio de Janeiro: Garamond.

Pinho PM, Pamplona VMS. Ramos EMLS. 2013. Avaliação nutricional em quilombolas Marajoaras. Belém: UFPA/ PROEX, 2013.

Piperata BA, Dufour D. 2007. Diet, energy expenditure and body composition of lactating ribeirinha women in the Brazilian Amazon. Am J Hum Biol. 19(5):722-734.

Piperata BA, Spence JE, Da-Gloria P, Hubbe M. 2011. The nutrition transition in Amazonia: Rapid economic change and its impact on growth and development in ribeirinhos. Am J Phys Anthropol. 2011, 146:1-13.

Piperata BA, Schmeer KK, Hadley C., Ritchie-Ewing G. 2013. Dietary inequalities of mother-child pairs in the rural Amazon: Evidence of maternal-child buffering? Social Sci. \& Medicine, 96, 183-11.

Popkin BM. 2003. The nutrition transition in the developing world. Dev Policy Rev., 21:581-597. 
Queiroz, HL. 2005. A Reserva de Desenvolvimento Sustentável Mamirauá: Um modelo de alternativa viável para a proteção e conservação da biodiversidade na Amazônia. Dossiê Amazônia II - Rev. Est. Avançados - IEA/USP, 19(54):183-203.

Rodrigues CI. 2006. Caboclos na Amazônia: A identidade na diferença. Nov. Cad. do NAEA., 9(1): 119-130.

Rose G. 1985. Sick individuals and sick populations. Intern J of Epidemiol, 14: 32-38.

Rosinger A, Tanner S, Leonard W, TAPS Bolivia Research Team. 2013. Precursors to overnutrition: The effects of household market food expenditures on measures of body composition among Tsimane' adults in lowland Bolivia. Soc Sci \& Med, 92:53-60.

Salles V. 2005. O negro no Pará sob regime de escravidão. 3a Ed. Rev. Ampl. Belém: IAP, Programa Raízes.

Santos AKCR, Carvalho BM, Bortolini MC, Santos SEB. 2008. Amazonian Africandescendant populations: mapping a people's social-biological interactions through mtDNA. Genet Mol Biol. 31:12-22.

SBEM (Sociedade Brasileira de Endocrinologia e Metabolismo). 2010. Atualização das diretrizes para o tratamento farmacológico da obesidade e do sobrepeso. Brasília: SBEM.

SBH (Sociedade Brasileira de Hipertensão). 2010. VI Diretrizes brasileiras de hipertensão - DBH VI. Avaliação clínica e laboratorial e estratificação de Risco (cap. 3). Rev. Bras. de Hipertensão; 17(1): 18-21.

Silva HP. 2001. Growth, development, nutrition and health in Caboclo populations from the Brazilian Amazon. Ph.D. Dissertation. Department of Anthropology. Columbus: The Ohio State University.

Silva HP. 2002. Aspectos demográficos e médico-epidemiológicos dos residentes na Floresta Nacional da Caxiuanã, Melgaço, Pará. In: Lisboa PLB (Ed.) Caxiuanã: Populações Tradicionais, Meio Físico e Diversidade Biológica. Belém: MPEG/MCT; 7794.

Silva HP. 2004a. Impactos da degradação ambiental na saúde humana: desafios para o século XXI. Soc. Méd. Rev. 11: 8-11.

Silva HP. 2004b. Saúde e doença em relação ao meio ambiente: desafios para as populações em situação de vulnerabilidade. Coleção Estudos Temáticos sobre os Objetivos de Desenvolvimento do Milênio: Saúde. Belo Horizonte: IDHS, PNUD, PUC Minas, 108110 .

Silva HP. 2006. A saúde humana e a Amazônia no século XXI: reflexões sobre os objetivos do milênio. Nov. Cad. do NAEA, UFPA,; 9(1):77-94.

Silva HP. 2009. Socio-ecology of health and disease: the effects of invisibility on the caboclo populations of the Amazon. In: Adams C, Murrieta RSS, Neves WA, and Harris 
M. (Orgs.). Amazon Peasant Societies in a Changing Environment: Political Ecology, Invisibility and Modernity in the Rain Forest. New York: Springer, 307-333.

Silva HP. 2011. Life is hard, life is beautiful: Some perspectives on Amazonian rural population's health and aging. In: Pinedo-Vasquez M, Ruffino ML, Padoch C, Brondízio ES. (Eds.), The Amazonian Varzea: The Decade Past and the Decade Ahead. New York: Springer, p. 11-36.

Silva HP. 2015. Local populations, bioanthropological research and the promotion of public health in Amazonia. Am J Phys Anthropol, 156(S60):304.

Silva HP, Eckhardt, RB. 1994. Westernization and blood pressure variation in four Amazonian populations. Collegium Anthropol., 18(1):81-87.

Silva HP, Padez C. 2010. Body size and obesity patterns in Caboclo populations from Pará, Amazonia, Brazil. Ann. Hum. Biol., 37(2):218-230.

Silva HP, Crews DE, Neves WA. 1995. Subsistence patterns and blood-pressure variation in two rural Caboclo communities of Marajo Island. Pará, Brazil. Am. J. Hum. Biol., 7:535-542.

Silva HP, James GD, Crews DE. 2006. Blood pressure, seasonal body fat, heart rate, and ecological differences in Caboclo populations of the Brazilian Amazon. Am. J. Hum. Biol., $18(1): 10-22$.

Silveira, IM, Kern, DC, Quaresma, HDAB. 2013. Reconstruindo uma ocupação. In: Lisboa, PLB (Ed.). Caxiuanã: Populações Tradicionais, Meio Físico e Diversidade Biológica. Belém: MPEG/MCT, 59-76.

SISVAN. 2008. Orientações para a coleta e análise de dados antropométricos em serviços de saúde. Norma técnica. Brasília: Ministério da Saúde.

Treccani GD. 2006. Terras de quilombo, caminhos e entraves do processo de titulação. Belém: Girollamo Treccani.

Urlacher SS, et al. 2016. Heterogeneous effects of market integration on sub adult body size and nutritional status among the Shuar of Amazonian Ecuador. Ann Hum Biol ??:????.

Weiner JS, Lourie JA. (Eds.) 1981. Practical human biology. New York: Academic Press.

WHO - World Health Organization. 2000. Obesity: Preventing and managing the global epidemic. WHO Technical Report Series, n. 894. Geneva: WHO.

WHO - World Health Organization. 2011. Obesity and overweight, Factsheet No. 311. Available in: http://www.who.int/mediacentre/factsheets/fs311/en/

Wirsing RL. 1985. The health of traditional societies and the effects of acculturation. Curr Anthropol., 26:303-322. 